\begin{tabular}{|l|l|l||}
\hline \multicolumn{2}{|c|}{ PublisherInfo } \\
\hline \hline PublisherName & $:$ & BioMed Central \\
\hline \hline PublisherLocation & $:$ & London \\
\hline \hline PublisherImprintName & $:$ & BioMed Central \\
\hline \hline
\end{tabular}

\title{
Consequences of patrilocality
}

\begin{tabular}{|l|l|l||}
\hline \multicolumn{2}{|c|}{ ArticleInfo } \\
\hline \hline ArticleID & $:$ & 4187 \\
\hline \hline ArticleDOI & $:$ & $10.1186 /$ gb-spotlight-20010828-01 \\
\hline \hline ArticleCitationID & $:$ & spotlight-20010828-01 \\
\hline \hline ArticleSequenceNumber & $:$ & 258 \\
\hline \hline ArticleCategory & $:$ & Research news \\
\hline ArticleFirstPage & $:$ & 1 \\
\hline \hline ArticleLastPage & $:$ & 2 \\
\hline \hline & & RegistrationDate : 2001-08-28 \\
ArticleHistory & $:$ & OnlineDate $\quad$ 2001-08-28 \\
\hline \hline ArticleCopyright & $:$ & BioMed Central Ltd2001 \\
\hline \hline ArticleGrants & $:$ & \\
\hline \hline ArticleContext & $:$ & 130592211 \\
\hline \hline
\end{tabular}




\section{Jonathan B Weitzman}

Email: jonathanweitzman@hotmail.com

Patrilocality (in which a woman moves to her mate's residence upon marriage) and matrilocality (in which women stay put and the men move) should be reflected in intra- and inter-group differences in the diversity of Y-chromosome and mitochondrial DNA sequences, inherited from the father and mother, respectively. In the Advance Online Publication of Nature Genetics, Oota et al. put this to the test by comparing Y-chromosome and mtDNA diversity in three matrilocal and three patrilocal tribes in northern Thailand (DOI:10.1038/ng711). They analysed 360 base pairs from the mitochondrial DNA first hypervariable region and short tandem repeat (STR) loci from the Y chromosome, and found that the mitochondrial DNA haplotype diversity was higher in all the patrilocal groups, whereas the Y-STR diversity was greatest in the matrilocal groups. This analysis of Thai hill tribes emphasizes how genetic diversity is influenced by complex social behaviours.

\section{References}

1. Genetic evidence for a higher female migration rate in humans

2. Nature Genetics, [http://genetics.nature.com]

3. Y-STR Haplotype Reference Database for U.S. Populations, [http://www.ystr.org/usa]

4. Genetic evidence on the origins of indian caste populations. 